\title{
6. REQUIEM BY KARL JENKINS. AN ANALYTICAL APPROACH TO THE INTERWEAVING OF VARIOUS TRADITIONS IN MUSIC
}

\author{
Loredana Viorica Iațeșen ${ }^{15}$
}

\begin{abstract}
In the diverse space of contemporary music, the fascinating and controversial personality of the Welsh composer Karl Jenkins, which is surprising from several perspectives, stands out. Open to assimilating and processing music from various sources (academic, liturgical, folk, entertainment, oriental, exotic), the all-round musician Karl Jenkins impresses the public with unexpected artistic choices, giving up the hypostasis of instrumentalist of the jazz-rock band Nucleus and of the group Softmachine in favour of the postmodern creator he has become today, synthetizing trends from musical compositions of the last decades of the $20^{\text {th }}$ century. Once with the return to the functional system, either through minimalism or through neo-romanticism, the artist has successfully covered a potential sonority path of modern opposites, also evoking references to creative models of the past. We are referring to the musical valorizing of the sacred in a synthetic vision between tradition and innovation, in the works included in the Adiemus cycle, in the opus choir Missa for Peace and, more particularly, in the Requiem (2005), a significant score in the contemporaneity. The manner in which the composer, while resorting to a musical genre originating from the Roman Catholic cult and drawing on the liturgical text of the Mass for the dead, inserted Japanese poetry, written following the structure of haiku, belonging to representative authors - Gozan Koshigaya, Issho Kosughi, Hokusai Katsushika, Kaga-noChiyo, is highly surprising. This study aims to highlight the interweaving imagined by Karl Jenkins between the two cultures as well as to conduct a semantic analysis of an opus in which the relationships between music and words entail a highly emotional response.
\end{abstract}

Key words: requiem, liturgical song, haiku, Western European music tradition, call for entertainment genres, Japanese lyric, traditional Japanese instruments

\section{Introduction}

The discussion on the universalist musician Karl Jenkins, a clear supporter of the famous contemporary direction World Music, first of all entails some clarifications regarding the classification of a personality of many talents in the generous and meandered Postmodern space, in order to be able to offer some answers to the meanings of the sacred universe from the perspective of the contemporary artist. What is clear, though, is that, among the many facets of musical Postmodernism, Karl Jenkins opts "against intellectual complexity in sound art" (Nyman, 1993, p. 207; Amblard, 2013, p. 1389), a line drawn since the late $80 \mathrm{~s}$, creatively valued and theorized by the contemporary composer Michael Nyman. In the latter's opinion, and not only, the refusal of Modernism draws possible connections between classical, traditional and entertainment

\footnotetext{
15 Associate Professor PhD., "George Enescu" National University of Arts from Iaşi, Romania, email: iatesenloredana@yahoo.com
} 
music from the European and extra-European area - in other words, it resorts to the controversial and yet highly acclaimed world music ${ }^{16}$ style.

\section{The context of Postmodern British music}

The research conducted showed that Karl Jenkins is one of the Welsh creators who stepped in an individual manner in the direction of current British music. In one of the reference Romanian studies, i.e. Fenomene muzicale ale contemporaneităţii: muzica britanică şi finlandeză (2004) [Contemporary Musical Phenomena: British and Finnish Music] published in the volume Radicalizare şi guerilla [Radicalisation and Guerilla], the composer and musicologist Dan Dediu argues that, while the predominant musical culture in the 1960s was the Polish one, and the French and the German spectral music enjoyed supremacy a decade later, the 90 s stood for promoting the creation of two other cultures: the British and the Finnish (Dediu, 2004, p. 168).

By synthesising some of the relevant ideas of this research, we recall the so-called Modern-moderate creators, Peter Maxwell Davis, Paul Patterson, Alexander Goehr, Harrison Birtwistle, who capitalize on the neoclassical orientation. Another group is that of the radical modernists, who resort to innovative orchestration techniques or notation systems, which includes Brian Ferneyhough, Michael Finissy, James Dillon and Jonathan Harvey. Another generation targets British nonconformist composers: George Benjamin, Oliver Knussen, Mark Anthony Turnage, James MacMillan, James Clarke, Benedict Mason, Thomas Adés.

So where does Karl Jenkins fit in the context of contemporary British music? Somewhere between Jonathan Harvey - who is considered to be "exotic, visionary, inventive, mystic" (Dediu, 2004, p. 171), a musician who synthesizes various sources (European, Indian), author of unique timbre combinations, who resorts to minimalist music techniques - and Mark Anthony Turnage, who proposes a link between various sonorities of contemporary academic music and jazz (cool combinations mixed with polyrhythmic moments, with blues) - there is Karl Jenkins, a surprising musician, another supporter of openness to various sounds (backgrounds and styles), especially affiliated to the direction traced by James MacMillan, to English choral religious music, specific to the motet.

\section{Means of refusing Modernity from the perspective of language}

Refusing Modernity, a reaction voluntarily assumed by Karl Jenkins, applied in works subsumed to the religious genre (which will be dwelt on in what follows) can be explained by referring to the relationship between American Minimalism and Postmodernism. This is a context in which we are confronted with the recovery of late Romanticism from 1970-1980, when composers returned to the functional system, either through minimalism (a manner of organizing sonority in the tonal space), or through neo-romanticism

\footnotetext{
${ }^{16}$ The term refers to the traditional creation which was not integrated into the Western European space, the concept implying, in the last decades of the $20^{\text {th }}$ century, the global musical diversity of various cultures, spaces and ethnicities.
} 
(taking over creative landmarks from the $19^{\text {th }}$ century). The return to tradition can occur, on the one hand, radically (as in the case of neo-romanticism or of Arvo Päert's sonority of an extreme simplicity), and on the other hand, by tracing a route that includes New Simplicity minimalism and synthesis intonations from musical antecedence, into a possible harmonization with modernity (Sandu-Dediu, 2010, pp. 443-444). The American postminimalist composers (Meredidh Monk, Michael Torke, John Adams), those inspired from the pop, rock, jazz universe, taking over certain instruments or genres (Amblard, 2013), are in pursuit of this direction. Moreover, they themselves are practitioners of pop music, collaborating with vocal or instrumental artists, a particularity to which Karl Jenkins, a universalist musician, also adheres. Even adding a personal touch to language parameters (obsessive rhythmic structures, return to tonality, the use of natural resonance effects, of monody, of majorminor chord structures) targets, in the case of Jenkins and of other musicians of the time, the contemporary artist's openness to academic, traditional, entertainment sonorities, from the European and extra-European area.

\section{Karl Jenkins - a micro-portrait of a Postmodern musician}

By selecting only certain aspects of Karl Jenkins's career, we are amazed by the musician's prolific activity, connected to different types of timbres, by his openness to the intonations of a variety of geographical and cultural spaces, by this promoter of artistic products that are typical to the age of globalization.

Known as one of the most successful composers from the contemporary period, Karl Jenkins made his debut in music as an oboist in the Youth Orchestra of Wales. He studied music at Cardiff University and completed his specialized training at the Royal Academy of Music of London. Initially, he was a rock musician, a member of the jazz-rock band Nucleus and of Softmachine. Moreover, due to his creativity, to his innate sense of melody, to his talent to combine, synthesize, improvise on various themes, that quickly became hits, he was asked on many occasions to write music for various advertising campaigns, which facilitated his promotion, recognition and marketing. As a creator of academic music, he was unanimously recognised for his work Requiem, 2005, adding the launching of the albums: Adiemus: Songs of Sanctuary; Adiemus II: Cantata Mundi; Adiemus III: Dance of Time; Adiemus IV: The Eternal Knot; Adiemus V: Vocalise Adiemus Colores - Karadaglic/Villazon/Flores, 2013, Deutsche Grammophon; Motets - Polyphony / Stephen Layton, 2014, Deutsche Grammophon (Jenkins, 2016). The approach to popular contemporary genres (ambiental, film music) ensured a greater openness for this Postmodern creator, and especially a great appreciation of his music by officials (in 2005 and 2010 he was appointed officer of the Order of the British Empire, being distinguished by the Queen of England for his services in music).

After reviewing his fascinating career, the natural question is: what meaning could the use of sacred music have to a contemporary artist like Jenkins - the beneficiary of a secular music group, acting in various roles (instrumentalist, improviser, composer), oriented towards the profane musical 
area - in the context in which he focuses his energy on other genres, styles, intonations that are very different from one another in terms of state, spirituality, attitude? Naturally, the phenomenon under discussion also applies in the case of other musicians, an issue which will be debated in what follows.

\section{The meanings of the concept of sacred in Postmodern creators' view 5.1. Karl Jenkins' particular view}

Both in the European and in the American cultures, the use of minimalism and of the specific manner of organizing tone sonority are essential to creators who write religious opuses. This phenomenon has also encountered some exceptions, due to avant-guard musicians who believe that the sacred space entails the agglomeration of voices (textures, overlapping dissonant sound conglomerates) and the radicalization of language (atonalism, twelve-tone serialism, combination between the modal and the serial). Adapting language devices to some of the essential symbols that compose sacred aesthetics is surprising if we commence with the different responses to the state of prayer in Europe and America, more specifically from the obvious contradiction between deep spirituality and asceticism (manifested in Byzantine or Catholic rites), on the one hand, and the hippy, New Age spirituality (in an ecumenical interpretation), on the other hand.

"Building on the ostinato process must lead us to that esoteric trance, not only to describing an industrial, biological mechanism, according to Stravinsky's old ways. If Postmodernism voluntarily appears to be irresponsible from the perspective of aesthetics, abandoning the avant-garde, the historical obsession of the writing, it reveals itself to be responsible from an ethical perspective. For example, the image of Christ can stand out in relation to tonal language, to the ostinato technique" (Amblard, 2013, p. 1416). The same author believes that the fervor for religion that turned into Puritanism in the late $20^{\text {th }}$ century, an aspect which is more obvious in the Protestant than in the Catholic world, can be explained through the development of Postmodernism in the Protestant areas of the United States of America, the United Kingdom and Northern Europe: Denmark, the Netherlands, Sweden, Norway, Iceland, Estonia and Latvia (Amblard, 2013, p. 1417). A special case of the creator subjected to religious metamorphoses and to profound inner transformations is that of the Estonian Arvo Pärt, a supporter of Neo-Romantic aesthetic simplification, drawing inspiration from old music and related techniques, especially in choral and vocal-symphonic religious genres.

However, let us not forget that the Missa, Stabat Mater, Magnificat, Alleluia, Miserere, Requiem genres are a constant concern of the Postmodern creator who thus refuses Modernity. He most often associates the latter with the profane, where he integrates all other musical styles. In this manner, Postmodernism will unconsciously contribute to the revival of the concept of Divinity, as a reaction against the current domination of atheistic beliefs and discourses, conveniently interpreted as democratic. We recall Alfred Schnitke, Philip Glass, Krzysztof Penderecki's requiems (Polish Requiem, 1980-1984, 
reviewed in 1993), Henryk Mikołaj Górecki (Kleines Requiem für eine Polka, 1993), John Taverner (Celtic Requiem), Giya Kancheli (Bright Sorrow Requiem, 1984), Pēteris Vasks (Musica dolorosa, requiem, 1983), Valentin Silvestrov (Requiem for Larissa seul, 1979), to which various film scores (Requiem, 2001) by Vladimir Godár or Requiem for a Dream (2000) by Clint Mansell are added.

What is clear, however, is that the collection of sacred works listed above share some stylistic constants: natural resonance, the timbrality of string instruments, the taste for the minor mode, the use of minimalism, aleatorism, spectralism, or of different collage techniques, the preference for slowness of speech, as opposed to moments of extreme rhythmic dynamism, specific to entertainment sounds. These elements are also taken over by Karl Jenkins, with the understanding that, in his view, the sacred has an antinomical significance (in comparison with Arvo Pärt's aesthetics), in the sense that: the Welsh artist bears the risk of appearing to be more extroverted, more commercial (we are referring to the many areas of inspiration and sound processing); his creation does not necessarily require a framework for liturgical development; it is not unitary (the use of European, Celtic, Asian, exotic sources); it is, in his view, the opening to the entire world, which will receive, in concentrated form, the offer of all musicians in a single one. This is the difference from Pärt's introverted nature, seeking isolation, silence, in the space of just a few monodies, superposed in various forms of organum.

\section{Requiem in the late $20^{\text {th }}$ century and early $21^{\text {st }}$ century}

The metamorphosis of this genre is best outlined in the volume Recviemul românesc [Romanian Requiem] (2004) signed by the composer Adrian Pop. We resorted to this valuable systematization in order to capture some of the issues regarding the requiem from the $20^{\text {th }}$ century until present times. In the early $20^{\text {th }}$ century, the Vatican proposed to restore the function and purpose of the requiem by returning to Gregorian chant sources, more specifically, by reiterating the initial liturgical character. This movement resonated in some of the cultures which were open to revive the tradition of old music, yet most authors treated this genre more and more freely, given the historical, political and psychological changes which undoubtedly influenced its development. The requiem becomes a meditation on the great confrontations of humanity, orienting the communities towards ecumenism (Pop, 2004, p. 20). We remark upon the linguistic diversity of texts depending on their creators' belonging to a specific culture. One of the best known requiems remains War Requiem (1962) by Benjamin Britten, which comprises traditional requiem features and fragments of Wilfred Owen's poetic texts. Fragments of liturgical texts can also be found in Dies Irae by Penderecky (1967), where, apart from the religious material itself, fragments of psalms, texts by Aeschylus, Paul Valery, etc. are also used. In the time frame 1980 - 1984, Penderecki completed the score of the Polish Requiem, which stands out by its Postmodern revival of the sacred.

The requiem can also become a melting pot of collective memory, which also includes artistic extensions (review of styles, collages of citations from 
significant stages in the history of music or in the evolution of cultural epochs). We are referring to B. A. Zimmermann's Requiem for a Young Poet (19671969), which is dotted with insertions of various renowned works of music from the academic repertoire, entertainment, or of various poetic fragments written by significant authors of the $20^{\text {th }}$ century (Pop, 2004, p. 22). The requiem, like the other genres from the $20^{\text {th }}$ century, underwent transformations in the synthesis of stylistic sources, of works of music of various origins. This is also the case of Virgil Thompson's Missa pro defunctis (1960), which is a mix of intonations and rhythms specific to American music, "jazz, boogie-woogie, waltz, tango, various hymns, negro-spirituals" (Pop, 2004, p. 21). Andrew Lloyd Weber's Requiem is part of the same combination of sources. It synthesizes "musical" intonations (p. 21) with elements specific to the "Anglican tradition" (p. 21).

Given the sobriety of the themes proposed, the profound significance of death, the requiem remains connected with tradition. Regardless of whether they are sung in an ecclesiastical or in a non-liturgical environment, most authors do not completely disregard the the original Gregorian chants. Even if this genre becomes concertante, it laicizes, it amplifies, it connects with historical, political and social events. Its language and sound expression are innovated (i.e. excerpts from various sources, in terms of style and meaning, especially in the second half of the $20^{\text {th }}$ century). Essentially, it cannot be transformed radically, given the fact that the initial meaning of messa pro defunctis allows to take only a few liberties.

\section{Requiem by Karl Jenkins}

The Requiem is a reference score written by the composer Karl Jenkins, which preserves the tradition of the genre it represents, enjoying a phenomenal success at its first audition at the Southwark Cathedral in June 2005. In his extreme creativity, the composer resorted to the Latin text of the funeral mass, which he associated with highly lyrical Japanese funeral texts, in the form of haiku ${ }^{17}$, belonging to representative authors such as Gozan Koshigaya, Issho Kosughi, Hokusai Katsushika, Kaga-no-Chiyo, and Banzan.

\subsection{Analytical considerations}

Written for choir and orchestra, with an innovative timbral composition, consisting of traditional and Asian instruments (Shakuhachi-flute, 2 horns in F, percussion-timpani, Chinese bamboo, darbuka, tambourine; harp; string instruments), the requiem comprises the following 13 sections: Introit; Dies Irae; The snow of yesterday; Rex tremendae; Confutatis; From deep in my heart; Lacrimosa; Now as a spirit; Pie Jesu; Having seen the moon; Lux aeterna; Farewell; In paradisum. At first sight, the work presents architectural

\footnotetext{
${ }^{17}$ The haiku is a poem with a fixed structure, specific to the Japanese culture, consisting of 17 on or syllables, distributed on three symmetrical phrases of 5, 7 and 5 syllables. It is important for this poetical genre to include an expression inspired from nature, an element which hints to the season in which it was written. The author conceives a concentrated text, testing the reader's imagination and emotions, by configuring delicate scenes, the meaning of which has often remained undeciphered. Developed on two independent levels, in a simultaneous perception of poetical layers, the haiku becomes a deeply philosophical genre, being subjected to multiple interpretations.
} 
similarities to Mozart's Requiem, a different score from its initial form imposed by the Council of Trent, due to its missa structure which comprises 12 parts (Dies irae, Tuba mirum, Rex tremendae, Recordare, Confutatis, Lacrimosa, Domine Jesu, Hostias, Andante, Sanctus, Benedictus, Agnus Dei), based on six stanzas of a Latin poetic text from the $13^{\text {th }}$ century and on six liturgical texts from the funeral mass. Regarding the music, Wolfgang Amadeus Mozart's Requiem was a model for Karl Jenkins's work from the same genre, the Postmodern creator offering a sequence of simplified versions, in terms of sound and writing, or free improvisations, in the development of its 13 moments, Mozart's masterpiece being regarded as the obvious source of inspiration.

\subsubsection{Introit}

In the introduction, the composer synthesizes the original liturgical text from the sections Introitus, Kirie and Graduale, preserving the traditional structure imposed by the Council of Trent, which is a common feature of most religious sections: Requiem aeternam dona eis Domine et lux perpetua luceat eis (Eternal rest give to them, $O$ Lord, and let perpetual light shine upon them); Kirie eleison (Lord have mercy on us); Requiem aeternam dona eis Domine et lux perpetua luceat eis (Eternal rest give to them, O Lord, and let perpetual light shine upon them). The Introitus commences with a diatonic $\boldsymbol{\alpha}$ motif exposed by two horns in A minor tonality, which subordinates a simple aerated harmonic accompaniment, rendered by the chordophone instruments, in blurred dynamics, $m p$. (m. 1-4). From landmark A, the original motif is developed through melodic sequencing, chromaticism insertion, to $\mathrm{m}$ : II $\downarrow$ (B flat), using the harmonic variant $(\mathrm{G} \#)$, augmented $4^{\text {th }}$ scale, to $\mathrm{m}$ : IV $\uparrow$, minor-major (C sharp / C natural) relationship, with tempo: V (m. 5-18). The corresponding lyrics are: Requiem aeternam dona eis Domine et lux perpetua luceat eis (Eternal rest give to them, $O$ Lord, and let perpetual light shine upon them). The homonymous (A minor/A major) modulation marks the chance in the lyrics: Te decet hymnus, Deus in Sion, et tibi reddetur votum in Jerusalem (A hymn, O God, becometh Thee in Zion and $a$ vow shall be paid to Thee in Jerusalem).

Figure 1 (Introit, m. 1-13)

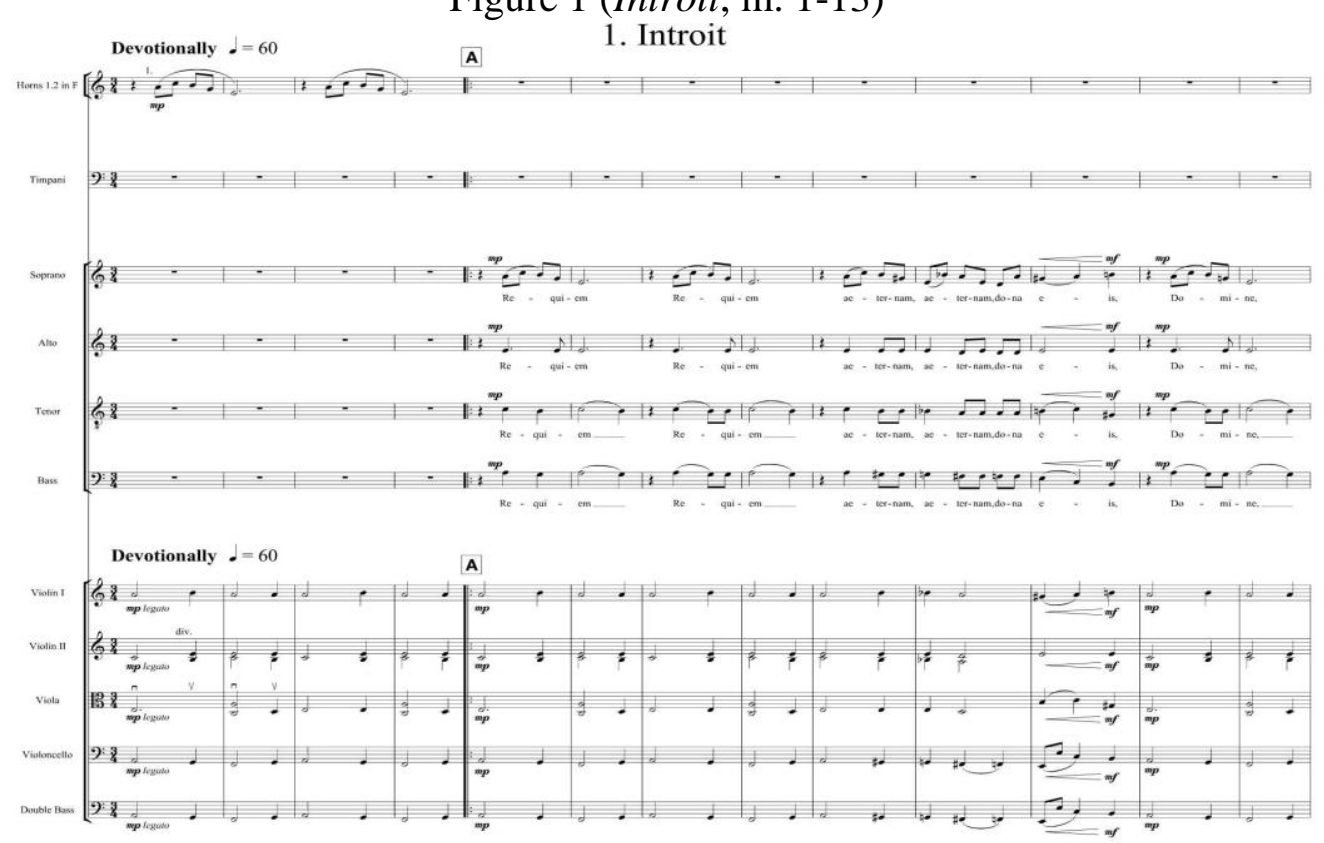


While section A (m. 1-18) can be interpreted as an antecedent moment, based on the melody (arching intervals, sequencing method), leading to an expanded motif (the theme of a fugue), section B (m. 19-26) has a consistent role.

Figure 2 (Introit, m. 14-26)

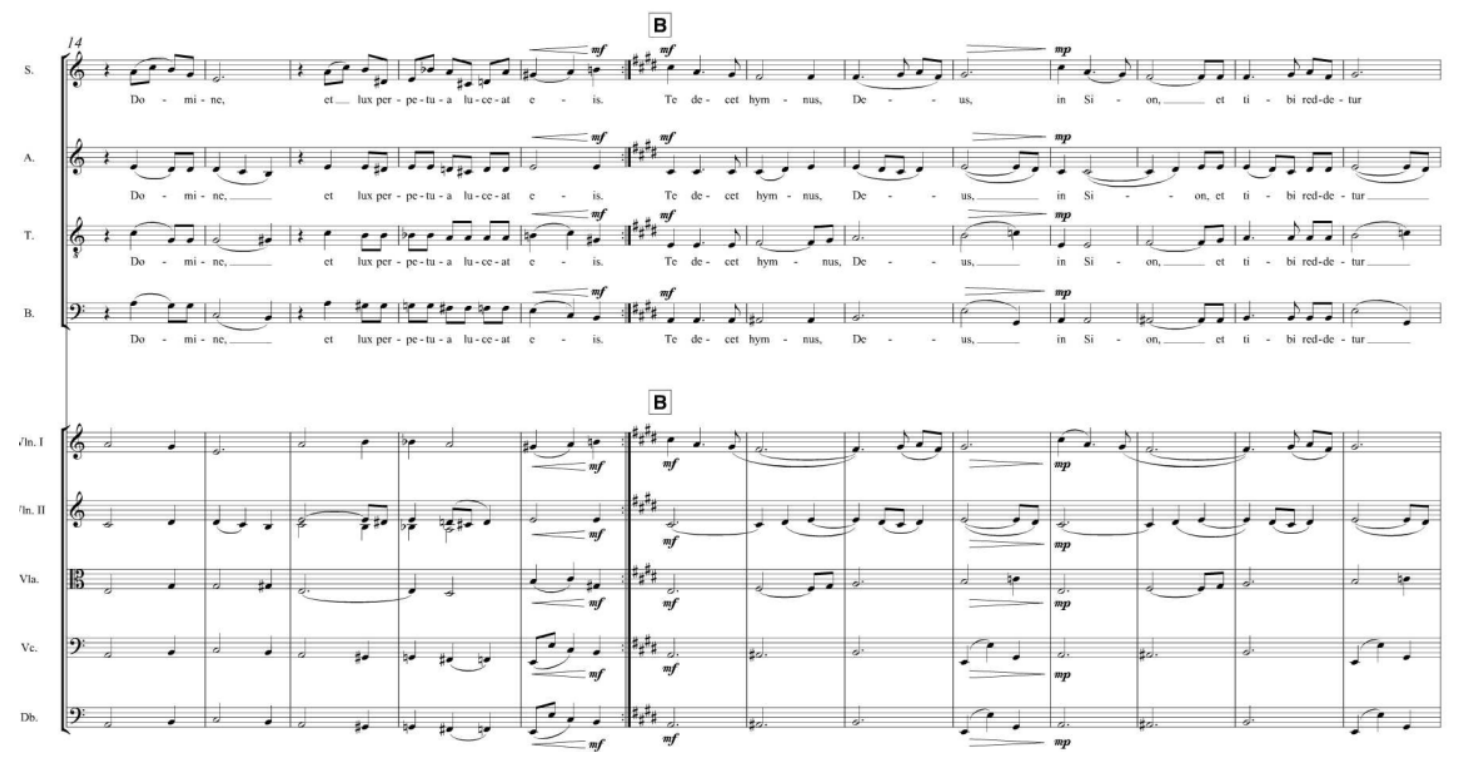

The $4^{\text {th }}$ altered diminished scale makes the transition to D flat major in section $\mathrm{C}$ (m. 27-38), the beginning of the next stanza being in A minor. The lyrics Exhaudi orationem meam, ad te omnis caro veniet ( $O$ Lord, hear my prayer, all flesh shall come to Thee) stress all the emotions that are emanating from this reference score. The following seven measures (m.39-45) belonging to section $\mathrm{D}$ entail a return to the initial theme in the two horns in F. Once we reach part E, we are confronted with the middle part of the entire Introit, developed in an alternation of homophone and fugue, corresponding to the text Kirie eleison. Its increased dramatism is due, on the one hand, to the dotted rhythm from the incipit of motif $\boldsymbol{\beta}$ and, on the other hand, to the contrapuntal treatment of voices. It should be noticed that the section Recviem aeternam could be perceived as an allusion to the introduction to Mozart's requiem, given that Karl Jenkins created a lyrical sound ambience (i.e. decreased number of instruments, simplified writing). The atmosphere in Kirie is more sober, classical, traditional, even though the Welsh musician wrote this section in free polyphony, the expressive melodic line being obvious through the variation of the initial motif (Kirie, m. 46-72). The leittheme Recviem aeternam in extenso (m.73-90) is reprised between parts (F-2 $\mathrm{m} \rightarrow \mathrm{G}$ ), in A minor tonality. It is followed by section $\mathrm{H}$, which repeats the same modulating path and the same lyrics aimed at achieving symmetry. The end is meant to be a short coda, materialized by repeating the word Requiem in A minor, on a diminished dynamic path, from $m f$, to $p p$.

\subsubsection{Dies Irae}

Focused on the violent images of the Last Judgment, full of confusion and terror, the well-known sequence Dies Irae (Day of Wrath) comprises illuminating lyrics: Dies irae, dies illa Solvet saeclum in favilla: Teste David et Sybilla (Day of wrath and doom impending. David's word with Sibyl's blending, 
Heaven and earth in ashes ending). In the composer's postmodern interpretation, this sequence is developed in extreme dynamism, which stands out from the introduction as a hellish race (drawing on rhythmic structures from hip-hop music) built on an ostinato of the low strings.

Figure 3 (Dies irae, m. 1-3)

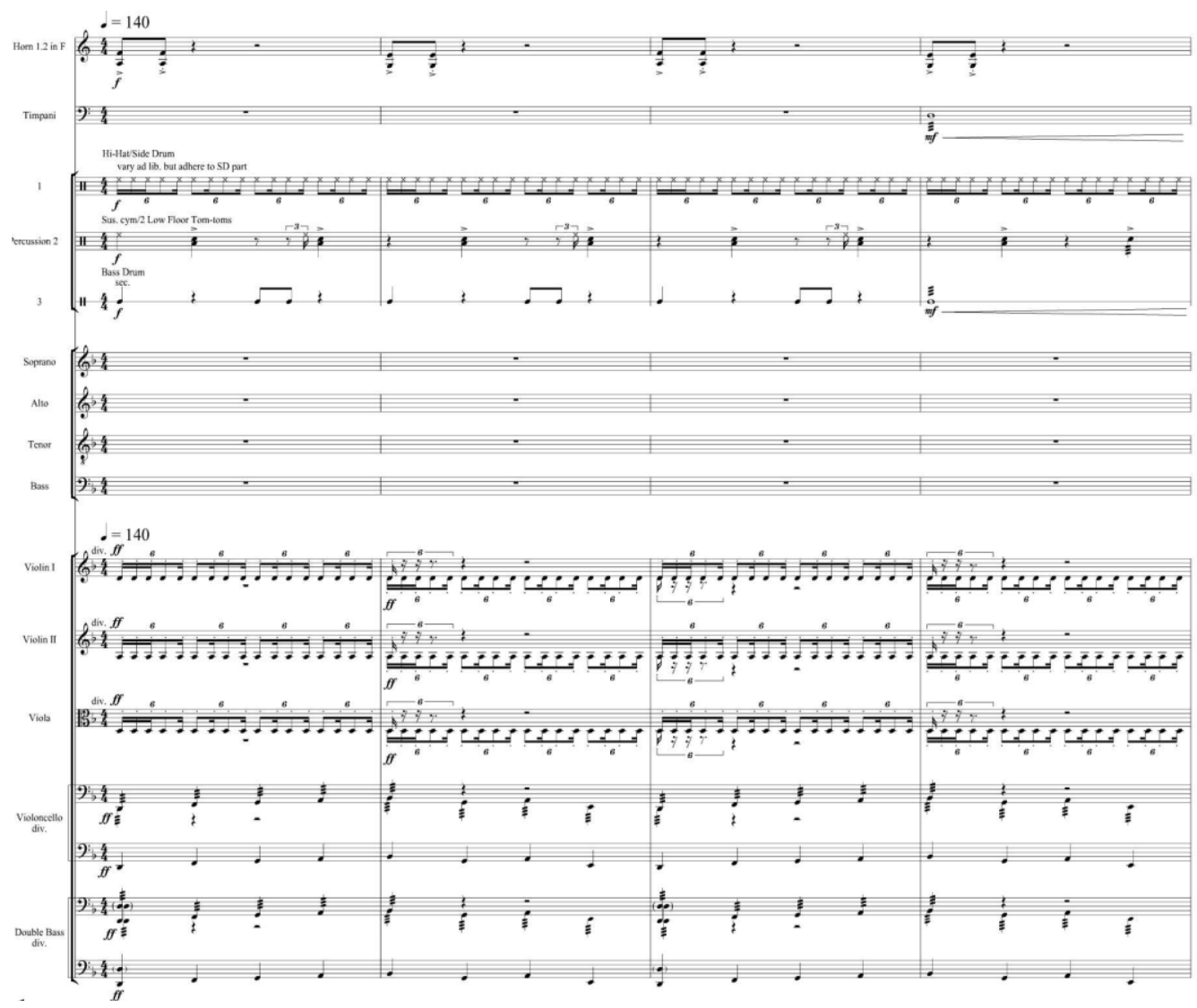

The violins continuously play the same dotted sounds, repeating the same note, interrupted by the horns at the end of the phrase, through a three-note syncopated motif, with ambitus of low third (which later becomes the basic material in the thematic exposure of the choir). The $f f$ tone has a predominant role. The structure of this section can be perceived as a rondo, Tuba mirum being interpreted as a chorus. The choir sings the lyrics based on three motifs: the first $(\boldsymbol{\alpha})$ is syncopated, leading to two accentuated rhythmic impulses, followed by a pause, in which various notes are repeated, and then doubled in the octave. The countermelody of the horns, chromatically evolving on three sounds, contributes to the dramatic effect. The second motif, $\boldsymbol{\beta}$, reproduces the dotted rhythm of the violin (ostinato on a sound), accentuating the first syllable. The third motif, $\boldsymbol{\Omega}$ (the chorus Tuba mirum), comprises a suite of augmented and then diminished third intervals, the previous melody being resumed in the ostinato technique. The words Dies Irae correspond to a repeated sound, which is doubled in the higher octave, an interval repeated by the choir in a violent minimalist way, in a continuous acceleration, until the end of this section. 
Figure 4 (Dies irae, m. 121-124)

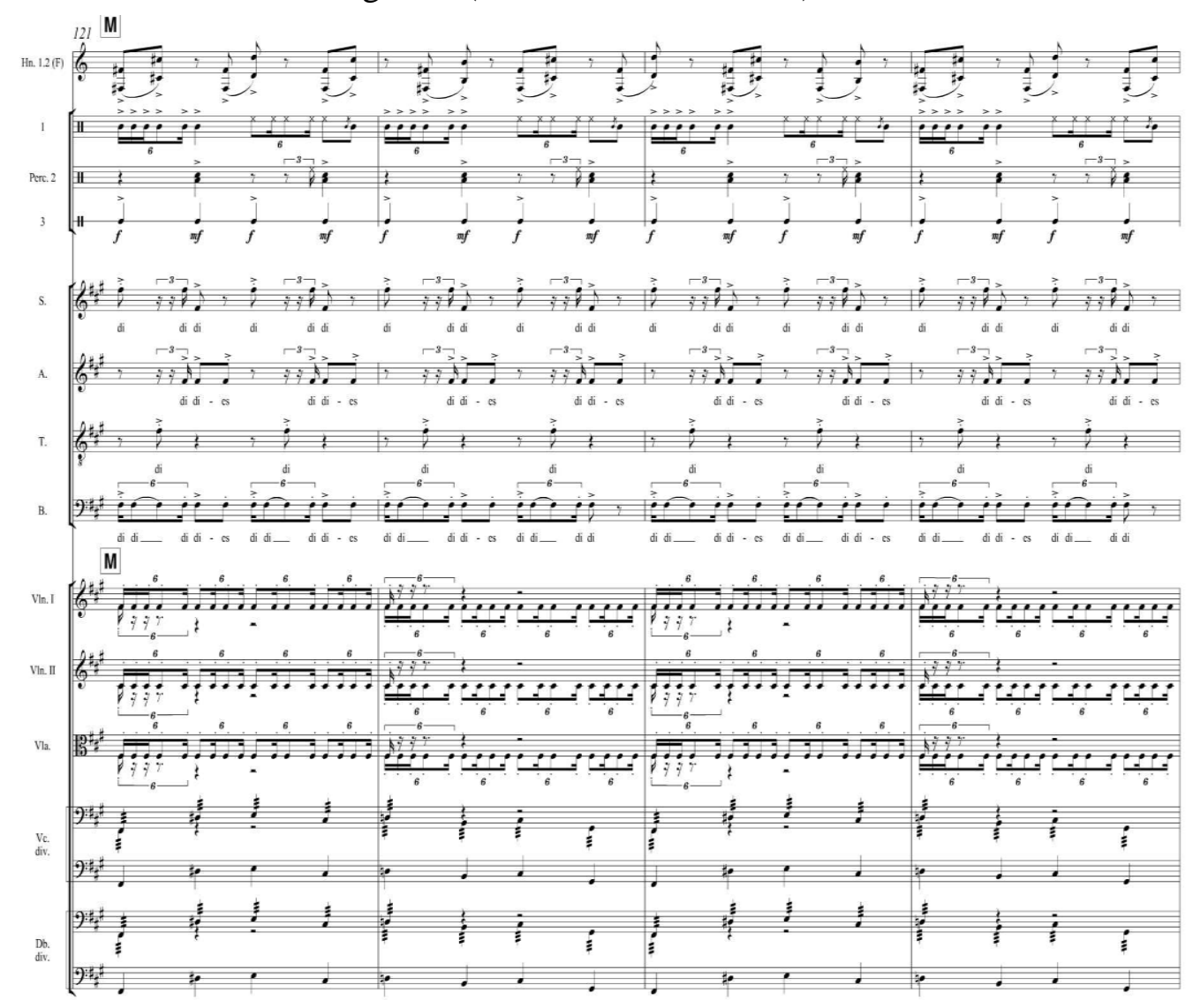

The final modulations increase the tension before reaching the conclusion, the countermelody being built this time on the initial motif, in a syncopated chromatic evolution, of the trombone. Unlike Mozart's version, Jenkins takes the dynamics of the traditional discourse to the extreme, offering an apocalyptic picture of the day of wrath.

\subsubsection{The snow of yesterday}

Inspired by the sensitive text of Gozan's Japanese haiku, Hana to mishi Yuki wa kinuozo Moto no mizu/ The snow of yesterday that fell like cherry blossoms is water once again, the composer creates a sensitive music of extreme simplicity. He uses a minimalist technique, Asian instruments (Shakuhachi, similar to the traditional flute; Chinese bamboo for percussion), as well as an antiphonal organization of the discourse (dialogue between soprano/chorus and instrumental ensemble), by resorting to isochronous and isorhythmic structures, in order to achieve a static, timeless character. In his economy of means, aimed at highlighting the pentatonic intonations that are resumed in an alternation of $\mathrm{E}$ minor and $\mathrm{F}$ minor tonalities, developed in fuzzy dynamics $(p p)$, the author uses the accompaniment of strings with an ample presence, interrupted in cadences by arpeggio structures, suggesting a state of meditation, of imponderability. In a clear contrast to the previous section, Dies irae, rhythmically charged, tense, The snow of yesterday can be interpreted as an escape in the pursuit of a primary space, the sacredness of which has been preserved intact. 
Figure 5 (The snow of yesterday, m. 1-10)

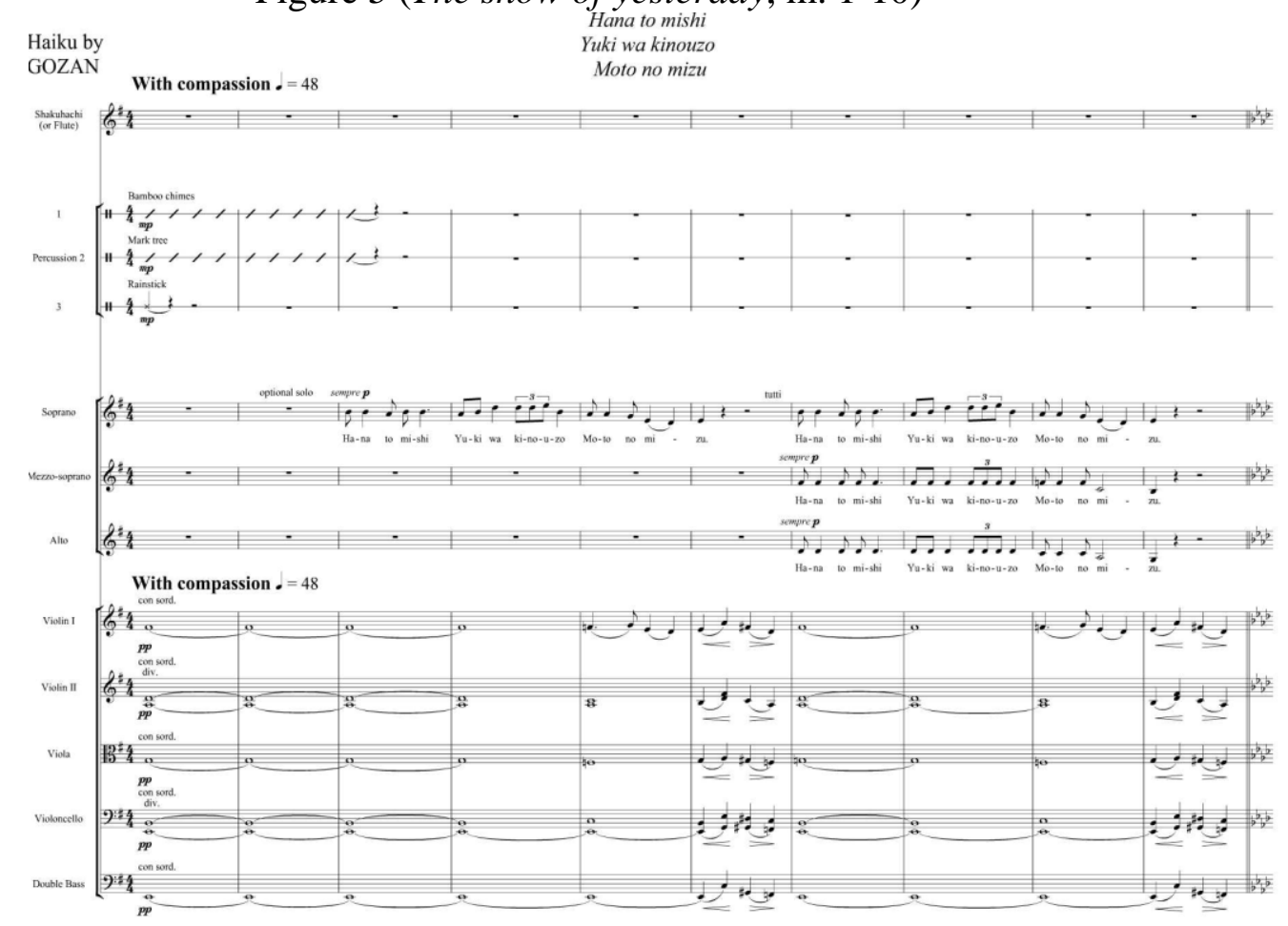

Being conscious of all the changes undergone by the religious genres throughout the ages, of their component parts (the section Dies irae changes its expression, structure, size, in relation to various parameters), the composer offers the contemporary audience another meaning of the term sacred, i.e. openness to Oriental sources and intonations. In his view, the Asian region emanates the purity which Western European countries have unfortunately lost in their development. The rhythmic and melodic entities, the pentatonic or anhemitonic structures brought forth by Karl Jenkins undoubtedly constitute a common musical background for the Western and Oriental cultural spaces.

\subsubsection{Rex tremendae}

The following musical moment is fully charged with religious semantics: Rex tremendae majestatis, Qui salvandos salvas gratis, Salva me, fons pictatis (King of Majesty tremendous, Who dost free salvation send us, Fount of pity, then befriend us!). This is a call for simplification, in which the composer opts for an isorhythmic and isochronic development of the choral music in F major tonality, in the rigorous dotted accompaniment of the percussion. We are referring to the image created, with the different sound and suggestion of the grand purifier (purged of fear, anxiety) from the grand oppressive (shattering) of the same section from other scores belonging to the same genre, signed by Mozart or Verdi, where the correspondence between the meaning of the text and music is direct.

In his requiem, Karl Jenkins highlights the symbolic image of the text, the other significant details being eluded. The result is a score of great simplicity, which combines the Gregorian melody with reduced intervals and with the ternary meter specific to medieval secular songs. The repetition of symmetrical rhythmic and melodic structures reminds us of the similar architecture present in 
those chansons polifoniques from the $13^{\text {th }}-14^{\text {th }}$ centuries. In our attempt to interpret the rhythmic and melodic entities of extreme simplicity, in the context of the evolution of the genre, we are surprised to discover that the postmodern creator's vision is to offer us a new beginning of the sacred, through concentration and simplification, through repetition, as a symbol of perenniality. The result is a construct of poetry and sound, conceived in the absence of exaggeration, pathos or restlessness, due to the fact that Karl Jenkins wishes to convey a clear message to his contemporaries, representing, in fact, the synthesis of the original text written following the decision of the Council of Trent: Fount of pity, then befriend us!

\subsubsection{Confutatis}

The stanza Confutatis maledectis, Flammis acrisbis addictis; Voca me cum benedictis (When the wicked are confounded, Doomed to flames of woe unbounded, Call me with Thy saints surrounded) reveals a calm musical score for the choir, in F major, the only changes in colour being made by the melodic tonality, through countermelodies played by the flute or harp, adding the subtle rhythmic dotting of the percussion. Interestingly enough, the musician takes over from Mozart's homonymous piece only certain passages, in a variational manner, on which he builds the entire musical development, excluding the tension of the dotted rhythmic and melodic structures, thus simplifying the orchestration to the maximum. While the entire rhetoric of Mozart's discourse evolves through the contrast of expression and to all parameters of language on an ascending line, towards the climax reached in $p p$, Karl Jenkin equalizes, simplifies expression, keeping only the essential.

\subsubsection{From deep in my heart}

Inspired by Issho's poem (kokoro kara Yuki utsukushi ya Nishi no kumo), Karl Jenkins makes another call for musical purity (From deep in my heart / how beautiful the snow! / clouds in the west). We enter this realm first and foremost through the pentatonics played by the refined Asian instrument Shakuhachi, which is complemented by the female voices singing (soprano, mezzo-soprano, alto) in unison, in the discreet accompaniment of chordophones.

The insertion of subtle vocal effects contributes to the mystery of this musical piece, by dividing the sopranos. A part of the ensemble sings syllables from the haiku poem in staccato, piano and counterpoint, while the second female group repeats the same pentachord, suggesting the search for tranquillity. This part of the score seems to be inspired from reality, the composer using simple yet extremely suggestive means. For example, he insists on faded dynamics ( $p-p p)$, resorts to intimist, desolate poetic expressions, renders certain vocal accents in reduced tones. These are just some of the arguments that could be advanced to support the idea conveyed by the composer, that of reviving the sacred in other cultural spaces, which are related to the primordiality of feeling, of the word, of the static. The composer resorts in these free non-liturgical sections to the creation of non-evolutional sound images, in order to metaphorically immortalize eternity, or so it seems. 


\subsubsection{Lacrimosa}

Lacrimosa is known as the most lyrical section integrated into the requiem genre: Lacrimosa dies illa, Qua resurget ex favilla, Judicandus homo reus. Huic ergo, Parce, Deus. Pie Jesus Domine, dona eis requiem, Amen (Ah! that day of tears and mourning, From the dust of earth returning, Man for judgement must prepare him, Spare, O God, in mercy spare him. Lord, allpitying, Jesus blest, Grant them Thine eternal rest. Amen). This part also contains the most elaborate music of the entire score. The composer offers, if we may say so, a noble variation of Mozart's model to which we have referred on countless occasions in our study. After a short introduction, which is meant to create the atmosphere, which uses Western and Asian instruments (harps, darbukas and chordophones), the image of an old music is depicted, the compact sonority being associated with the timbre of the lute. Lacrimosa is sung in unison by the entire choir in an emotional ethereal crescendo.

Figure 6 (Lacrimosa, m. 1-6)

7. Lacrimosa

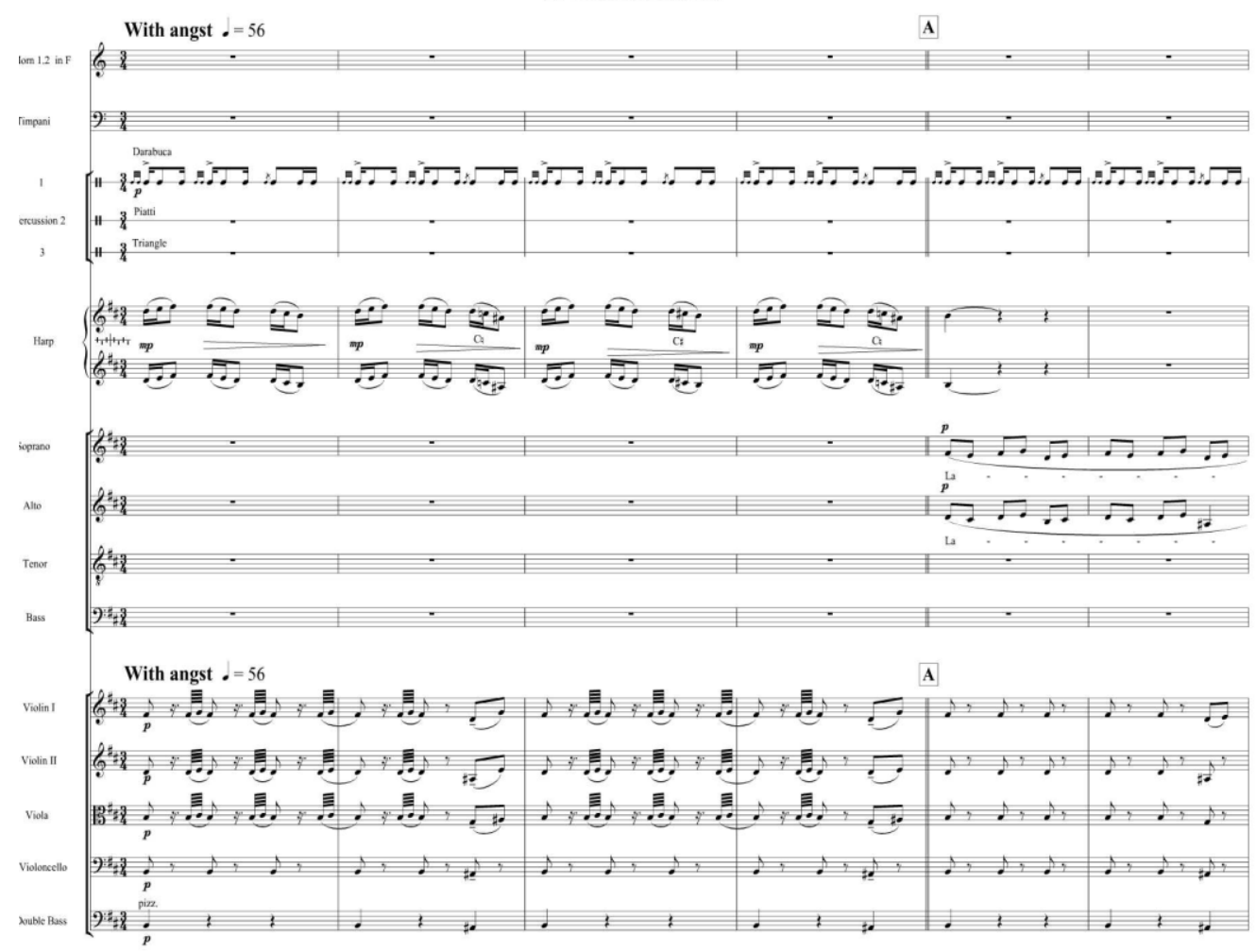

The sound variation, created through the mobility of the scales (majorminor oscillation, alteration of the $4^{\text {th }}$ scale from D major with lyrical inflections, the use of known variants, harmony and melody) creates the synthesis between the tonal and the modal, between two different musical cultures. The contrasts in the musical score stand out. The composer resorts to harmonic structures, to ample dynamics, in order to underline the verses Pie Jesus Domine, dona eis requiem (Pious Lord Jesus, Give them rest), alternating with the vocals from the ascending melodic and harmonic sequences, and especially with the homophone moment corresponding to the word Amen, when the voice of the soprano takes over the melody, and the others are meant to accompany the theme in crescendo. 


\subsubsection{Now as a spirit}

In the following section, the composer resorts to the haiku written by Hokusai Hitodama de Yukuki sanjiya Natsu no hara (I shall roam the summer fields). The correspondence with this poetic text is designed on the background of the dynamics of the tempo, in a mysterious ambiance, in the development of which the musician uses the semiquaver in a continuous performance of the chordophones and of other instruments with a relevant timbre (i.e. harp, percussion, Shakuhachi). The sopranos, alternating with the altos, sing simple pentatonic, diatonic or chromatic melodic formulas (the mobility of the $4^{\text {th }}$ scale) in high rhythmic values. The sound effect makes clear reference to the Asian cultural space, as well as to an original time in which the spirit from the present is in a perpetual search of its former self.

\subsubsection{Pie Jesu}

The section Pie Jesu (Pie Jesus Domine, dona eis requiem. sempiternam requiem / Pious Lord Jesus, Give them rest. Everlasting Rest), performed in slow tempo, in pure neoromantic style, is extremely inspired. How is this ambience of piety accomplished? The composer combines the liturgical text from Agnus Dei (Sequenta 5) with the timbre of two horns in F, of the harp and of a soloist violin, which engage in dialogue with the entire ensemble in rarefied dynamics and, especially, with a solo tenor. He sings the famous lyrics Pie Jesus Domine, dona eis requiem in alternance and dialogue with the soprano, continued by the melodic violin. The melody is extremely simple; it is a Gregorian chant of absolute purity.

Figure 7 (Pie Jesu, m. 1-10)

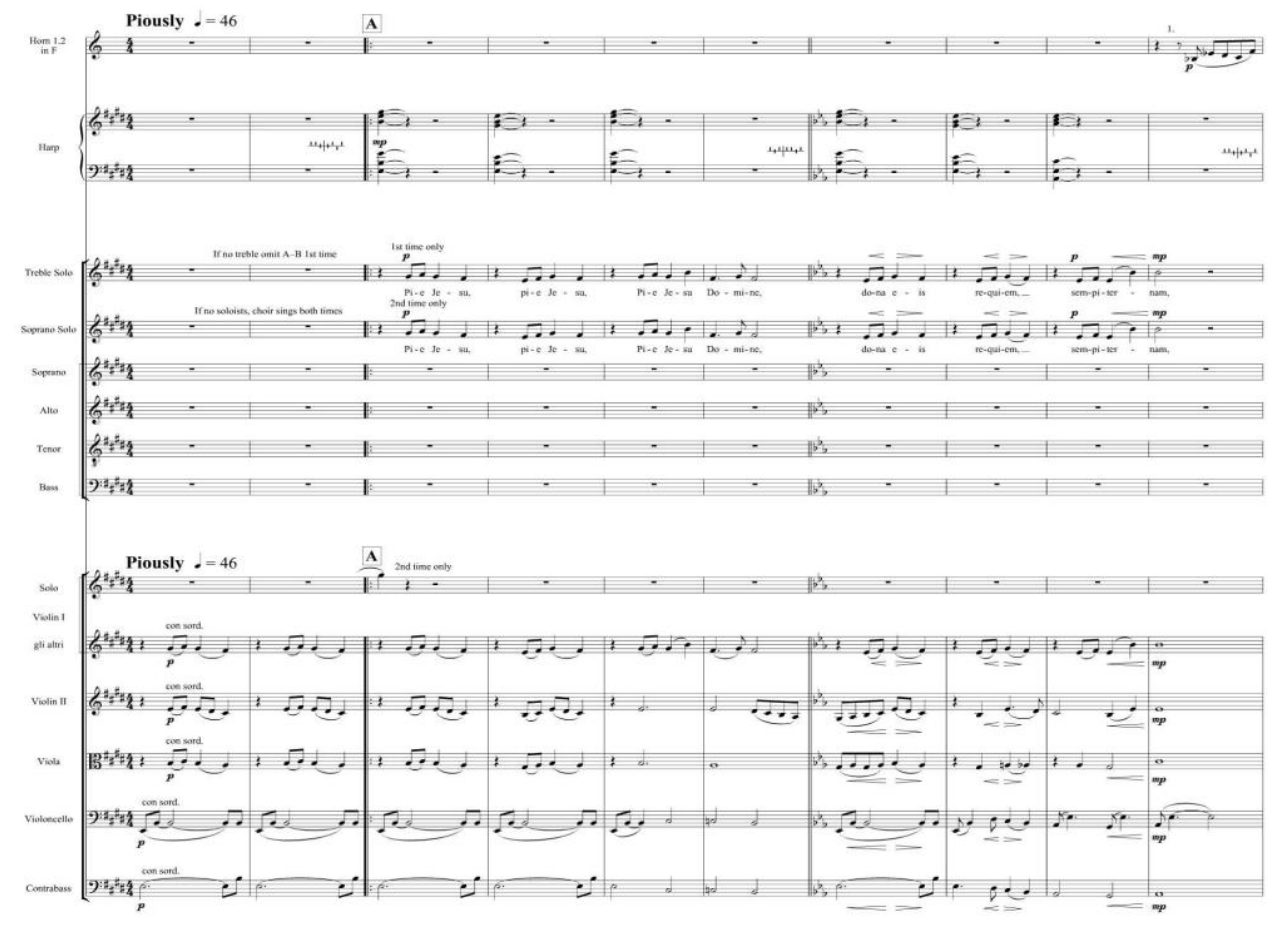

\subsubsection{Having seen the moon}

Regarding the text and music, Karl Jenkins superposes two cultures in an original way. The tradition of the Catholic, liturgical song is highlighted through the text from Sanctus Benedictus qui venit in nomine Dominil Blessed is he who 
comes in the name of the Lord, interpreted by the men's chorus in the form of a sequence from a Gregorian chant, symbolizing the reiteration of past into the present. The composer highlights the static by means of an achordic pedal (superposing the A minor triad with an added quartet structure). The resulting harmonic structure recomposes the severe, austere ambience from Medieval cathedrals, where early polyphony forms such as organum paralel were sang. The intervention of the women's choir consists in interpreting the pentatonic melodic formulas corresponding to the lines from the Japanese haiku (Tsuki mo mite Ware wa konyowo kashiku kanal Even I take leave of this life with a blessing), the meaning of the test being similar to the liturgical lyrics. In terms of timbre, the ambiance of a faraway Asian world is brought to the fore through sounds, throught the countermelody exposed to the mysterious Shakuhachi.

Figure 8 (Having seen the moon, m. 1-10)

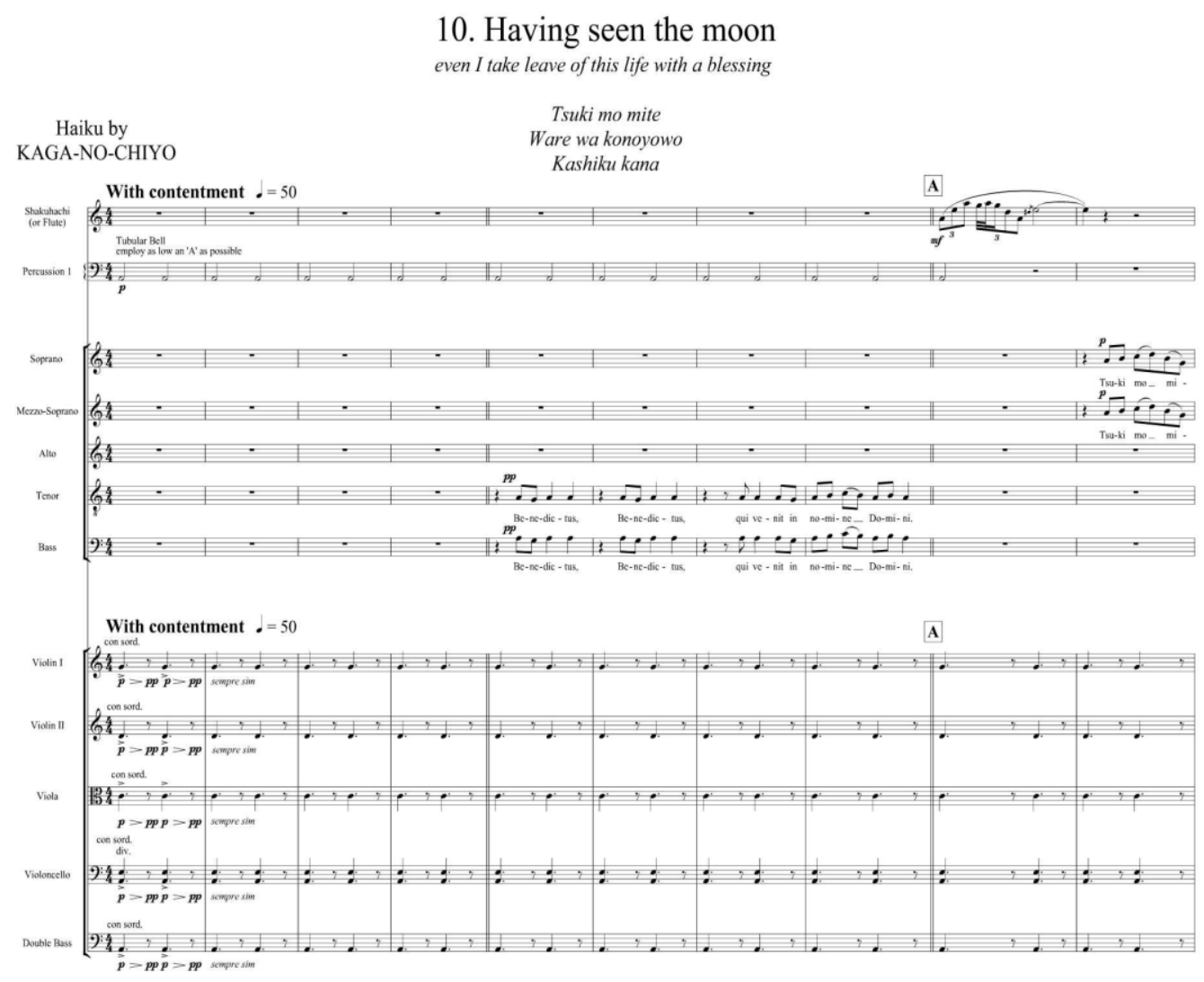

Thus, the composer superposes not only texts from different cultures, but also musical structures with a special sonority which, surprisingly, blend together perfectly. The sacred space becomes an aspiration for all communities, regardless of relition, ethnicity, culture, or tradition. The openness to world music is not coincidental in Jenkins' work. For the creator of the music dedicated to the famous project Adiemus or Missa for Peace, composed with melodic and timbral inspiration, the combination of intonations from several cultures is a manner of achieving stylistic individuality in a Postmodern world in which such blends become almost a means of ensuring creative survival.

\subsubsection{Lux aeterna}

In the section Lux aeterna, the Jenkins resorts to the text from Communio - Lux aeterna luceat eis, Domine: Cum sanctis tuis in aeternum, quia pius es. 
Requiem aeternam dona eis Domine Et lux perpetua luceat eis. Cum sanctis tuis aeternum, quia pius es / May everlasting light shine upon them, O Lord, with thy saints in eternity, for thou art merciful. Grant them eternal rest, $O$ Lord, and may everlasting light shine upon them. With Thy saints forever, for Thou art kind, creating a sound synthesis through the timbre combination proposed in the discourse (two horns in F, darbuka, tambourine, triangle and chordophones). Moreover, the musician opts for the pentachordic melodic formula transposed on different modal centres, which is repeated as a leitmotif throughout the discourse, evoking and strengthening the relation with the Oriental space. Furthermore, the timbre solo, accompanied by a dotted rhythm, also reminds us of the relationship with various musical creations from the nonacademic field, which is more than welcome in this harmonic, timbral and melodic context. The lyrics follow a simple Gregorian melodic line, which is no more no less than a different rendering of the vocal part from Lacrimosa.

\subsubsection{Farewell}

The correspondence between the lines from Bazan's haiku (Mame de iyo Miwa nara washino Kusa no tsuyu / I pass as all things do like dew on the grass) is achieved on static music, by superposing a different pedal on an achordic pedal, in the form of a line from a Gregorian chant (Agnus dei qui tollis peccata mundi/Lamb of God, who takes away the sins of the world) sang in unison my the male group, above which a pentatonic melodic formula is played, transposed on different levels, according to the relation with the lines from the haiku. The Shakuhachi, the creator of exotic atmosphere, is not missing either. Not coincidentally, the composer writes the indication Serenely at the beginning of the movement, this ambiance succeeding in transposing it with the help of concentrated musical means, thus creating the image of a transcendent world.

Figure 9 (Farewell, m. 1-9)

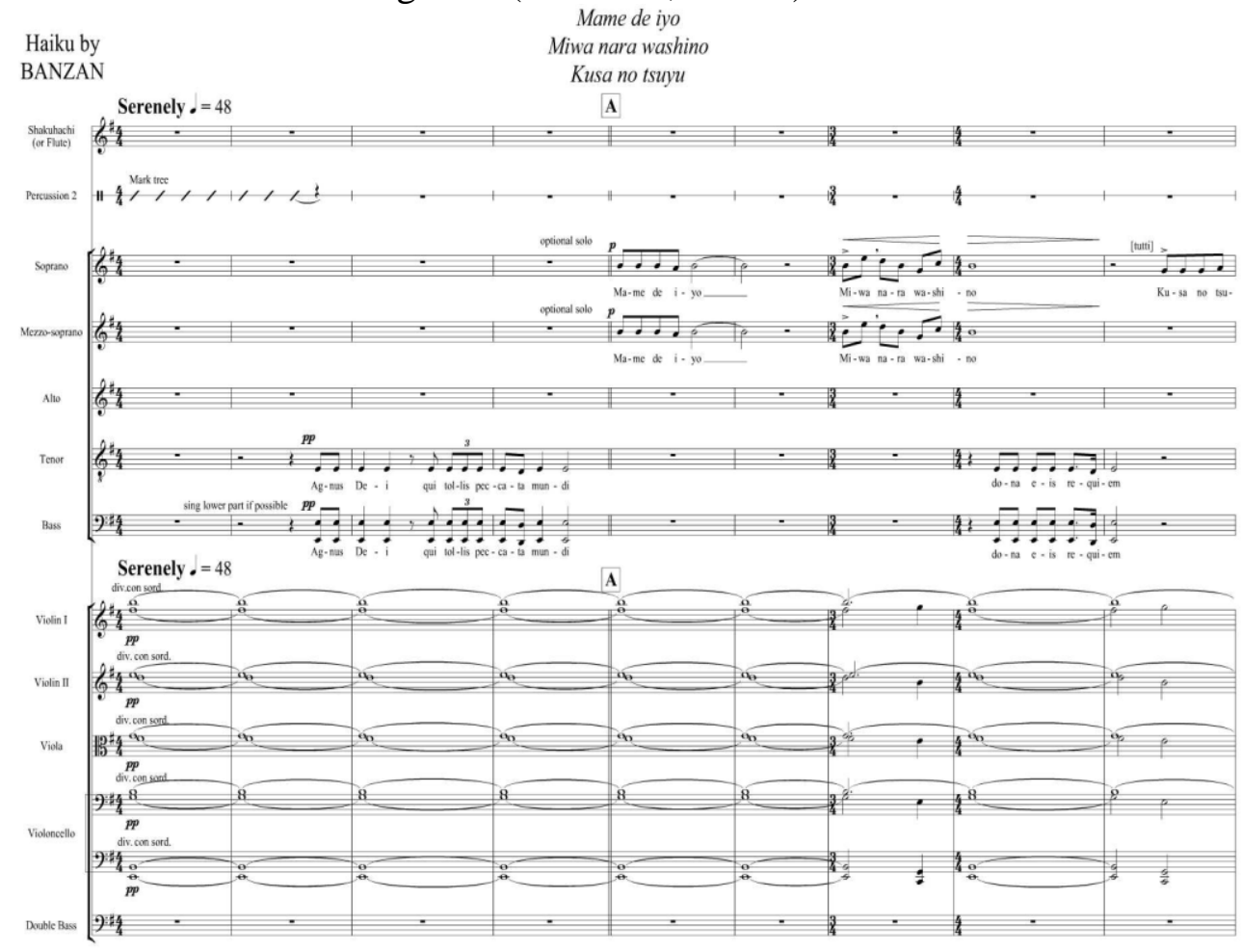




\subsubsection{In paradisum ${ }^{18}$}

The final section is concentrated from every point of view. The vocal part plays a secondary role, with the instruments playing the main part, especially during the ample harp improvisation. The message is simple: In paradisum deducant te Angeli; in tuo adventu suscipiant te Martyres, et perducant te in civitatem Sanctam Jerusalem. Chorus Angelorum te suscipiat, et cum Lazaro quondam paupere aeternam habeas requiem / May the angels lead you into paradise; may the martyrs receive you at your arrival and lead you to the holy city Jerusalem. May choirs of angels receive you and with Lazarus, once (a) poor (man), may you have eternal rest. The composer ideally believes that that which the voices cannot render, from a melodic perspective, can be conveyed by the harp, which, in its purity, becomes another potential messenger of the call for the unification between music and humankind.

\section{Conclusions}

Our analysis of Requiem by Karl Jenkins reveals the sensible connection which the composer created between the Western and the Oriental cultures, as well as the close correspondence between music and lyrics, the musician offering Postmodern receivers a duality of expressive forms: on the one hand, he urges us to dwell on meditation, on recollection, on the return to spirituality; on the other hand, he proposes a brighter and hopeful vision in recomposing the sacred universe, accessible to different receivers, regardless of their religious denomination.

\section{Bibliography}

1. Amblard, J. (2013). Postmodernisme. In N. Donin \& L. Feneyrou: Théories de la composition musicale au XX siècle (2nd vol., pp. 1387-1424). Lyon: Symétrie, pp. 1387-1424.

2. Dediu, D. (2004). Fenomene muzicale ale contemporaneităţii: muzica britanică şi finlandeză. In Radicalizare şi guerilla (pp. 168-176) Bucureşti: Editura muzicală.

3. Jenkins, K. (2016). Retrieved from http://www.karljenkins.com.

4. Nyman, M. (1993). Against Intellectual Compelxity in Music, Postmodernism. A Reader. (Under the direction of Thomas Docherty, pp. 206-213). New York: Columbia University Press.

5. Sandu Dediu,V. (2010). Muzica postmodernă. In Dicţionar de termeni muzicali (pp. 443-444). Bucureşti: Editura Enciclopedică.

6. Pop, A. (2004). Recviemul ca tradiţie şi semnificaţie. In: Recviemul românesc (pp. 15-26). Cluj-Napoca: Editura MediaMusica.

\footnotetext{
${ }^{18}$ Into paradise is an antiphon from the traditional Latin liturgy of the Western Church Requiem Mass.
} 